\title{
Early warning system on extreme weather events for disaster risk reduction
}

Sistema de alerta temprana ante eventos climáticos extremos para la reducción del riesgo de desastres

\section{Jacipt Alexander Ramón Valencia (iD) ${ }^{1}$, Jordi Rafael Palacios Gonzalez (iD ${ }^{2 *}$, German Ricardo Santos Granados (iD) ${ }^{2}$, Jarol Derley Ramón Valencia}

${ }^{1}$ Grupo de Investigaciones Ambientales Agua, Aire y Suelo (GIAAS), Departamento de Ingeniería Ambiental, Universidad de Pamplona. $\mathrm{Km} 1$ vía Bucaramanga. C. P. 543050 . Pamplona, Colombia.

${ }^{2}$ Centro de Estudios Hidráulicos, Escuela Colombiana de Ingeniería Julio Garavito. AK 45 (Autonorte) \# 205-59. C. P. 111171. Bogotá, Colombia.

\section{CITE THIS ARTICLE AS:}

J. A. Ramón, J. R. Palacios,

G. R. Santos, J.D Ramón.

"Early warning system on extreme weather events for disaster risk reduction", Revista Facultad de Ingeniería Universidad de Antioquia, 92, pp. 96-104, Jul-Sep 2019. [Online]. Available: https://www . doi.org/10.17533/ udea.redin. 20190628

\section{ARTICLE INFO:}

Received: February 12, 2019

Accepted: June 28, 2019

Available online: June 28, 2019

\section{KEYWORDS:}

Climate change adaptation, atmosphere, community participation, weather forecasting

Adaptación al cambio climático, atmósfera, participación de la comunidad, predicción del tiempo

\begin{abstract}
The objective of this research was to propose a strategy based on the design and implementation of an early warning system (EWS) for extreme weather events. This project had the following phases: training for municipal and regional actors, preliminary technical diagnosis of the study areas, monitoring network, and the weather forecasts using numerical models WRF and GFS. This EWS is the result of the Macro-project EWS for Climate Events in the basins of the Pamplonita River and Zulia in the North of Santander (SATC), executed by the University of Pamplona and financed by the National Risk Management Unit (UNGRD) and the German Cooperation Agency (GIZ). The research concluded that the application of a disaster risk reduction strategy through an EWS for extreme weather events is an important tool and instrument for the planning of higher risk management because it helps anticipate disasters and consequently preserve lives.
\end{abstract}

RESUMEN: El objetivo de esta investigación fue proponer una estrategia basada en el diseño e implementación de un sistema de alerta temprana (SAT) para eventos climáticos extremos. Este proyecto tuvo las siguientes fases: capacitación para actores municipales y regionales, diagnóstico técnico preliminar de las áreas de estudio, red de monitoreo y pronósticos meteorológicos utilizando modelos numéricos WRF y GFS. Este SAT es el resultado del Macro-proyecto SAT para Eventos Climáticos en las cuencas del río Pamplonita y Zulia en el norte de Santander (SATC), ejecutado por la Universidad de Pamplona y financiado por la Unidad Nacional de Gestión del Riesgo (UNGRD) y La Agencia de Cooperación Alemana (GIZ). La investigación concluyó que la aplicación de una estrategia de reducción del riesgo de desastres a través de un SAT para eventos climáticos extremos es una herramienta e instrumento importante para la planificación de la gestión del riesgo porque ayuda a anticipar desastres y, en consecuencia, a preservar vidas.

\section{Introduction}

In recent years, the recurrence and the intensity of climatic variability phenomena such as ENSO, El Niño and La Niña, has caused critical impacts that affect

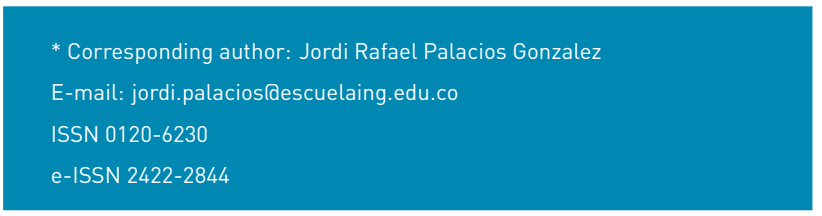

human lives and economic dynamics in the region. The evidence reveals a deficit of hydro-climatic information which affects the generation of early warnings to mitigate impacts at short, medium- and long-term difficulties. This condition influences the reaction the authorities can have to face theses eventualities taking into account disaster risk management, in particular support measures and decisions that must taken by departmental and municipal disaster risk management councils [1]. In the case of the North Santander Department, a lack of a hydro-climatic 
network was reflected, as well as, the difficulties to obtain updated information that serves as tools for the prevention of landslides and floods. It is worth mentioning that these phenomena have aggravated the environmental and socioeconomic crisis in the Department. To understand this situation some concepts presented below must be explained.

\subsection{Climate change and climate variability}

The UN Framework Convention on Climate Change [2], in its Article 1, defines climate change as "climate change attributed directly or indirectly to human activity that alters the composition of the global atmosphere and that adds to the natural variability of the climate observed during comparable periods of time". It also states that there is a difference between climate change "attributable to human activities that alter the atmospheric composition and climatic variability attributable to natural causes" [3]. On the other hand, from the meteorological point of view, climate change is called the alteration of the prevailing conditions. External processes such as the variation of solar radiation, variations in the orbital parameters of the earth (the eccentricity, the inclination of the earth's axis with respect to the ecliptic), the movements of the earth's crust, and volcanic activity are factors that have great importance in climate change.

According to [4], the climate varies in scales of time and space. Over the years, since ancient times, climate fluctuations have occurred at various time scales. In general, these fluctuations are caused by changes in the form of interaction between the different components of the climate system and by changes in the radioactive factors of forcing; in relatively short periods of time, in which the difference in the climate change occurs over long or very long periods of time. These fluctuations occur in the values of the climatological variables such as temperature, precipitation, among others, which are compared with a normal value.

The sequence of these oscillations around normal values is known as climatic variability and its assessment is achieved by determining the anomalies [5]. The climatic variability scales classify the temporal scales of climatic variability, as intra-seasonal scale (summer, rain intensification, etc.), seasonal scale (rainy, dry seasons, etc.), inter-annual scale (teleconnections and cycles lasting more than a yearl and scale between decades (climatic fluctuations). Therefore, ENSO El Niño and La Niña phenomena are associated with temporal climate variations and the Southern Oscillation. The inter-annual behavior in the superficial thermal field of the central region of the Tropical Pacific defines the presence of the phenomena associated with the El Niño and La Niña -
Southern Oscillation cycle. When the pressure is high in the Eastern-Central Pacific sector, it decreases in the western part and vice versa. This effect is known as the Southern Oscillation indexes (IOS), which is obtained from the normalized differences in atmospheric pressure between Tahiti (Central Pacific) and Darwin (Western Pacific). The negative phases of the IOS correspond to warming of the surface of the Tropical Pacific in the central and eastern sector. With the help of IOS, it is possible to identify the El Niño episodes that occurred in the last one hundred years [5]. This reversal of the surface atmospheric pressure gradient between the eastern and western regions of the southern Pacific Ocean can result in an inversion in the circulation of winds on the surface of the tropical Pacific Ocean. The coupling between these two phenomena, defined as El Niño - Oscillation of the South, ENSO or ENOS, is causing climatic consequences in a large part of the world. [6].

\subsection{Impacts of the ENSO phenomenon in Colombia}

In general terms, it can be said that the ENSO phenomenon generates a climate effect in Colombia that affects the economy, population and infrastructure of the country. [5] mention that the affectation of the rain regime by the warm phase of the cycle (El Niño) does not follow a common pattern, that is, it has not been the same during its occurrence in the last 5 documented events nor the same in all regions. However, they suggest that in the presence of the phenomenon the precipitation of the Andean, the Caribbean and northern regions of the Pacific region decrease while the opposite occurs in the south of the Pacific region, the southwest of the Colombian Amazon and some areas of the Piedmont foothills. This has a direct effect on the river flows and the natural supply of water, especially when the phenomenon is intense and persistent.

In the same way, the effect of the Niño phenomenon increases the amount of ultraviolet radiation that reaches the surface of the earth. The predominance of dry weather favors the increase in hours of solar brightness and consequently the amount of incident solar radiation, which includes the ultraviolet part of the spectrum [5]. At a socioeconomic level, the impact that the El Niño phenomenon has in different countries is very significant. For instance, the 1972-1973 and 1982-1983 events impacted the fishing sector in Peru, whereas the hydroelectric resources in Colombia were affected by the 1991-1992 phenomenon. [7] The climatic effect of this phenomenon is not limited to the tropical America region but extends to other latitudes and regions of the planet. For example, droughts in northern Australia, heat waves or floods in North America and Europe due to the El Niño phenomenon are well-known. 
In Bolivia and Colombia, the impacts are predominantly related to droughts and, to a lesser extent, frosts. More than $50 \%$ of the losses that occurred in Colombia were due to higher costs in the provision of basic electricity and water services, while in Bolivia the main damages are related to the productive sectors, especially agriculture. In this country, in addition to the damages caused by droughts in the altiplano, it also caused extensive flooding in the Amazon River. In both Colombia and Bolivia, large-scale forest fires occurred. The losses amounted to more than 500 million dollars, which in Bolivia represented about $7 \%$ of the gross domestic product by 1997 and less than $1 \%$ in Colombia [7].

[8] mention that in the case of the cold phase of the ENSO (La Niña), more than half of the episodes documented to date have started in the second quarter of the first year. The rains during the first two quarters are practically normal in the five natural regions of Colombia. From that moment and during the three following quarters, the climatic effect reflected through the surplus of rain is clearly manifested in the Andean, Caribbean, and Pacific regions. For the second semester of the second year, the effect weakens noticeably and again the behavior of the rains is almost normal.

\subsection{Impacts of the ENSO phenomenon in Norte de Santander}

The Department of Norte de Santander is in the North of Colombia, on the border with the Bolivarian Republic of Venezuela. Its location on the eastern mountain range gives it a variety of ecosystems and hydrobiological richness that has not been alien to the effects of the ENSO phenomena, where there have been numerous negative impacts derived mainly from the alternation of periods of severe droughts and extreme rainfall. In this sense, the El Niño phenomenon generates an increase in temperature and a decrease in rainfall with respect to normal values, which translates into droughts, a significant decrease in flow and an increase in forest fires in some regions [3]. In the case of the city of Cúcuta, capital of the Department, it is one of the most vulnerable to the phenomenon, due to the fact that it is located in an area with high rates of scarcity, it registers under this phenomenon temperature above $40{ }^{\circ} \mathrm{C}$ and faces rationing of water caused by the low flow of the rivers that supply the municipal aqueduct (Pamplonita and Zulia).

The most recently recorded phenomenon (2009-II - 2010-I) caused increases in temperature, a decrease in rainfall and the flow of rivers and streams, which had a significant impact on the agricultural sector, due to serious damage caused by climatic nature. Causing significant economic losses in the region, mainly in crops such as coffee, corn, rice, cassava, bananas and vegetables where there was an increase in pests and needs for agrochemicals and irrigation, increasing production costs and in many cases decreasing the returns. The expected future effect is the migration of agriculture to higher places and/or changes in land use drastic and higher impact (mining or pastures), which end up generating displacement to the cities before the depletion of resources and low profitability of the field. On the other hand, the phenomenon of La Niña generates in Norte de Santander significant increases in rainfall that occur in short periods of time and exceed the capacity of conduction and evacuation of waters, which generate saturation of soils and floods.

Due to the misuse that has traditionally been given to the Department's soils, deforestation and the steep slopes, the landslides that are registered sediment the rivers considerably, registering, for example, for the last La Niña event [9], turbidity values that greatly exceeded the maximum work values of the aqueduct plants of the city of Cúcuta in the Zulia and Pamplonita currents, causing more than 800 thousand people to run out of water service in the metropolitan area of Cúcuta for several days.

The high rainfall in the region causes landslides on many roads (Figure 1), with the roads that connect Cúcuta and Pamplona being the most affected. Consequently, commerce, tourism and normal transit of the inhabitants of the region are affected.

\subsection{Definition of the concepts of the early warning system and risk}

The concept of the early warning system (EWS) is used in different contexts of risk management and is used as a tool for planning before extreme weather events. [10]. Some authors define the concept of EWS [11-14]. In each of these definitions, there are common elements that allow us to define an EWS as the set of tools, control devices, management capabilities, and technological tools, which key institutions identify to disseminate information in a timely manner to communities exposed to a risk, and whose result is mitigation measures aimed at reducing the effects of natural disasters and economic and life losses, as well as injuries [12].

Similarly, the risk is defined as "the combination of the probability of an event to occur and its negative consequences" [14]. Natural disasters and the consequent social, environmental and economic losses have led to the creation of risk management, which refers to social actions and processes aimed at minimizing the negative consequences of disasters, including post-disaster activities, like the rehabilitation and reconstruction of the territory. Risk management incorporates five main 


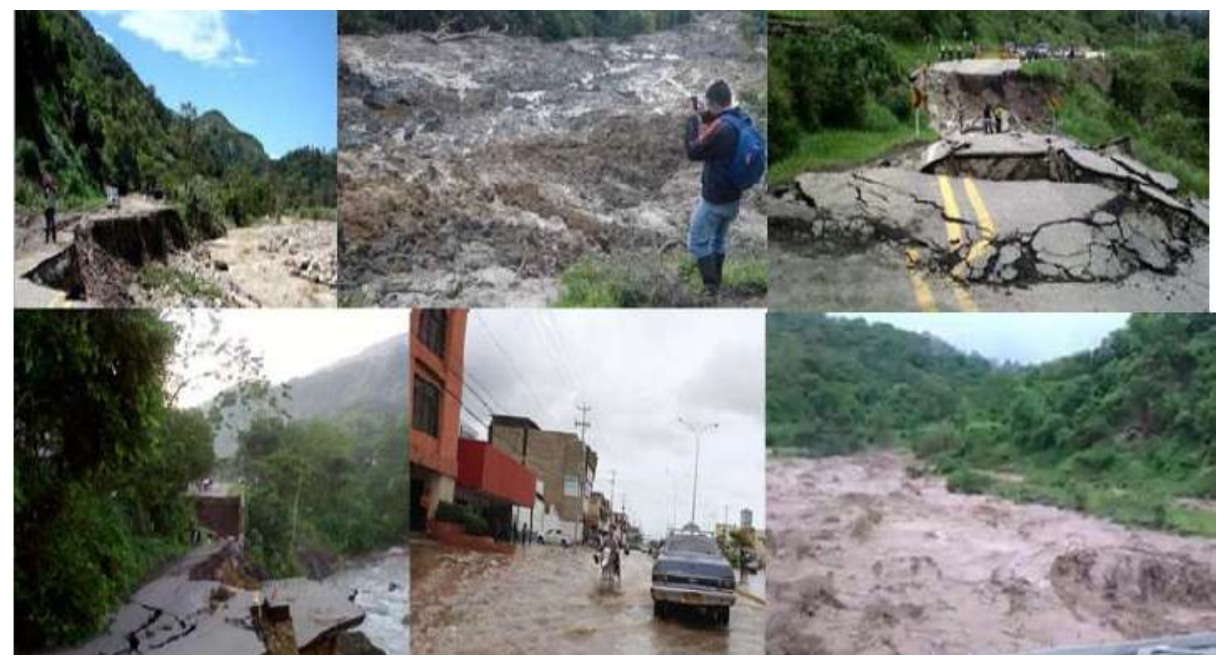

Figure 1 Some impacts of the La Niña Phenomenon (2010-2012) on the River basin

components: 1) the identification and evaluation of risk; 2) risk reduction; 3l financial protection; 4) preparedness and response to disasters, and 5) recovery after a disaster. The fourth component includes EWS (Figure 2) $[15,16]$.

\subsection{How does the adaptation to climate variability and risk management relate?}

From the perspective of vulnerability and its axes of analysis, climate adaptation measures should be aimed at providing solutions to reduce the magnitude of such vulnerability. For example, if the vulnerability is due to ignorance of the climatic threat and lack of information, a measure of adaptation would be aimed at improving knowledge and generation of climate information, which is precisely the scope of action of EWS and studies of the impacts of climate change on a given territory [17]. However, [18] states that from the perspective of Risk Management, the pillars that support it must be considered and then associated with Adaptation to Climate Change, as shown in Figure 3 [19].

An EWS consists in the rapid transmission of data to activate alarm mechanisms in a population previously organized and trained to react in an early and timely manner. The timely provision of information is done through the institutions in charge, which allows the people exposed to the threat to take action to reduce the risk and prepare for an effective response [20].

\section{Materials and methods}

The execution of the project was carried out in four phases contemplated during 24 months (2014 - 2015) in the following way: training for municipal and regional actors at the level of diploma courses and workshop seminars, in order to strengthen the knowledge surrounding the climatological systems; preliminary technical diagnosis of the study areas in the different municipalities belonging to the accounts of the Pamplonita and Zulia rivers; The monitoring sites for the network were determined through a study of the zones and conditions of signal transmission. Implementation of 11 automatic weather stations in real time, and 6 automatic hydrological stations in the municipalities of the Zulia and Pamplonita basins, which sends real-time hydrometeorological information to the platform (www . satnortedesantander. org), as shown in Figure 4. The general scheme of operation of the climatic network of the early warning system hydro climatological. General scheme of operation of the climatic network of the climatological hydro early warning system, which is articulated with the local alert centers, the real-time forecast through weekly bulletins easily accessible to the community and decision-making. The central server is located in the Main Alert Center in the city of Cúcuta (Colombia). Three hydrological stations were installed, one in the Pamplonita River, another in the Zulia River and the last in the Táchira River, carrying out calibration activities for the $\mathrm{H}$ (Height) curve. $\mathrm{Q}$ (Flow). The measurements of these stations will be made by trained local observers daily and sent to the Local Alert Centers. And finally, the weather forecasts were made using numerical models WRF and GFS.

We designed and carried out the assembly of the Web-SIG platform to access information on the EWS in the basins of the Pamplonita River and Zulia SAT in real time (WwW.satnortedesantander.org). It should be noted that forecasts are made using WRF and GFS numerical models of higher effectiveness and more than $80 \%$ of occurrence due to the analysis of the available 

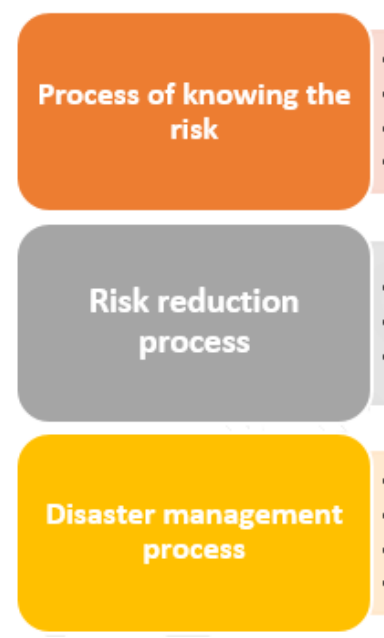

- Preparation for the answer

- Preparation for the recovery

- Execution of the response

- Execetion of recovery

Figure 2 Main components of risk management source: [18]

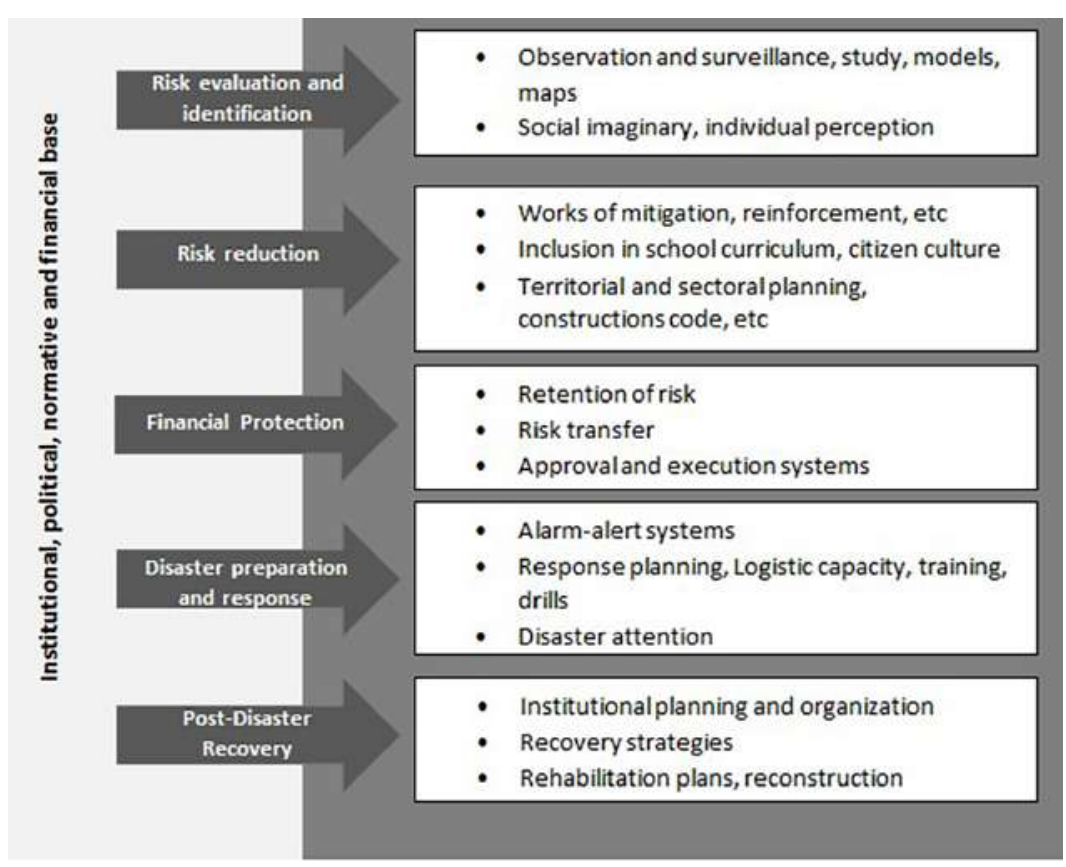

Figure 3 The Pillars of Disaster Risk Management source: [18]

free information of climatological data of wind direction and speed, temperatures, precipitation, solar radiation, and pressure, that are associated with the SAT Norte de Santander platform. For the design and assembly of the SATC platform, it was implemented through a web page under the HTML standard and javascript codes for the animations and display of real-time graphics of station instruments. However, there are servers for free web hosting if thinking about a very simple platform, or payment alternatives that would allow having unlimited storage and other options such as mail, databases, etc. The method of data transmission used is based on the so-called webtags, which function as templates and are constantly replaced by the current data of the weather station, whose configuration can be defined at will [21].

\subsection{Methodology for the design of the EWS strategy}

The design of the Community Participation Strategy included several actors, associations, producers, unions, universities, relief organizations, educational institutions, public and local, in order to include the concept of Risk and Disaster Management and the responsibility that each 


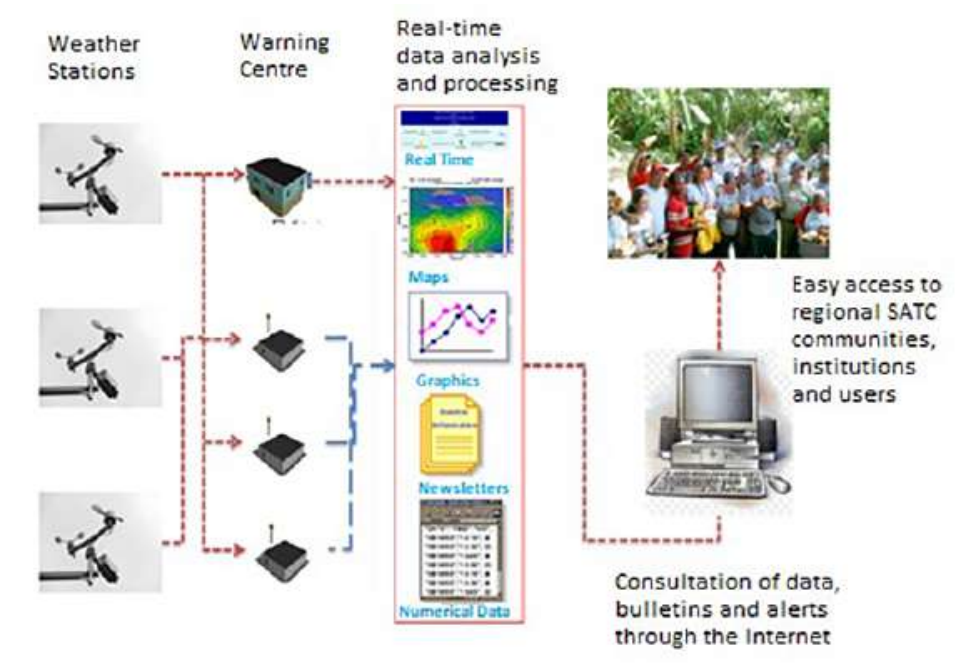

Figure 4 General scheme of operation of the climatic network of the early warning system hydro climatological

inhabitant must assume and respond to an eventuality. Another important element is the understanding of the scope of the different instruments of environmental planning that are interrelated in the territory with other instruments of regional and sectoral national planning. The consideration of these two elements shows that an early warning system should not only be seen technically but socially, integrating the two concepts can guarantee the sustainability of the project in the future.

The early warning system for extreme weather events present in the Department of Norte de Santander, uses the data of precipitation, dew point, wind speed, direction, pressure and temperature, thrown by meteorological stations, to predict a behavior and issue alerts that reduce the vulnerability of the risk in the region. The project was formulated considering two main phases: the first phase of Planning and the second phase of Execution, each one of the phases is designed according to the actions to be implemented and the expected products as shown in Table 1.

\subsection{Description of the study area}

The project contemplated the development in the zones of greater influence in the municipality of the department of Norte de Santander, such as the Pamplonita and Zulia river basin. Figure 5 [9] shows the basin of the Zulia river where the municipalities of Arboledas, Gramalote, Puerto Santander, El Zulia, Salazar, San Cayetano, Durania, Santiago, Salazar, and Villa del Rosario. Likewise, it is in the middle part of the department of Norte de Santander, on the eastern slope of the Colombian eastern mountain range. The basin is located between the North flat coordinate: 1'290.000 and 1`430.000 and East: 1`118.000 and 1'190.000, originating in the National Astronomical Observatory and part of the basin in the lower part continue to flow over Venezuelan territory.

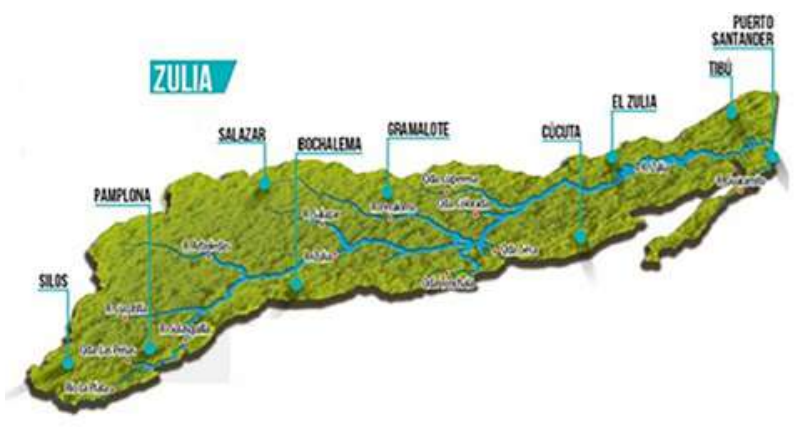

Figure 5 Location of the El Zulia river basin

This basin covers an area of 348,541 hectares (ha) (3485.4 $\mathrm{km}^{2}$ ), corresponding to $15.7 \%$ of the territory of the department of Norte de Santander. The greatest population influence in the department of Norte de Santander is found in the Pamplonita river basin through the municipalities of Bochalema, Herrán, Chinácota, Cúcuta, Ragonvalia, Toledo, La Bateca, Pamplona, Pamplonita, Los Patios and Puerto Santander (Figure 6) [9]. The basin is located on the eastern slope of the eastern cordillera of Colombia, southeast of the department of Norte de Santander and serves as the international boundary between Colombia and the Republic of Venezuela on the left bank with the Táchira River. This basin is comprised between North flat coordinates: 1'300,000 and 1'415,000 and East: 1'150,000 and 1195,000 . It comprises an area of 134,536 hectares $\left(1345.4 \mathrm{~km}^{2}\right)$, corresponding to $6 \%$ of the departmental area. 
Table 1 Font sizes for papers

\begin{tabular}{ll}
\hline Phase & Action to be implemented \\
\hline Planning & Design of the Project: \\
- Selection of Actors and creation of databases Socialization at Institutional Level \\
- Design of Agreements and Organizational structure and components for the \\
development of the strategy \\
- Design of profiles (Technical and Social) for the conformation of the Social, \\
operative and technical components \\
- Design of the processes and operating procedures, of management, of \\
evaluation and follow-up for the execution of the strategy \\
- Design of documentation Training Plan design \\
- Design of training and management manuals \\
- Design of the Operational Plan for the execution of the strategy \\
Personalized contacts with the different actors for the socialization of \\
the project in three levels: \\
- Institutional and management levels: \\
- Institutional Operating Producers and Civil society \\
- Formation of the Work Team \\
- Structuring of work areas - South (Herrán), Nort (Pamplona), \\
East (Puerto Santander) and West (Salazar) \\
- Training Work team (Processes, procedures, documentation, manuals) \\
- Conformation of a high-level commission for the management \\
and dissemination of the strategy and the expected results \\
- Workshop Design (Scope, contents, methodology): \\
- Type I Workshop: Zonal Workshops \\
- Type II Workshop: Workshops by Municipality \\
- Type III Workshop: Adaptation of agriculture to climate \\
change Workshop Programming \\
- Execution of Workshops: \\
- Evaluation and follow-up meetings by component and general of \\
all the components Quarterly evaluation reports \\
- Dialogues of exchange of experiences and perspective of the EWS \\
-
\end{tabular}

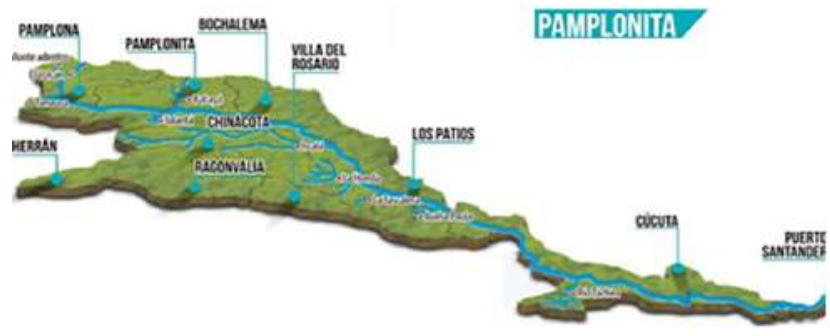

Figure 6 Location of the Pamplonita river basin

\section{Results and discussion}

The results of the investigation in two items are shown below: the operation of the EWS SAT and community participation.

\subsection{Operation of the EWS SAT}

By means of the design and assembly of the Web-SIG platform (Figure 7), we have access to the real-time SAT information of the 10 automatic meteorological stations monitoring with sensors the wind direction, wind speed, temperature, relative humidity, rainfall and atmospheric pressure; and the 6 automatic hydrological stations that monitor the level of rivers and real-time flow installed in different municipalities of the Zulia and Pamplonita basins. After the training of the actors, the reception of information from the stations, their processing, analysis, preparation of alerts, forecasts of the most prone to risk scenarios in the region such as floods, droughts, landslides due to rain and forest fires; it was articulated through contingency plans of mechanisms for the generation and communication of alerts, design of measures to adapt to variability and climate change in risk management in a collaborative manner with the communities [21]. 
Likewise, in addition, the forecasts were disseminated through periodic newsletters and media such as the Internet, email, local stations and text messages.

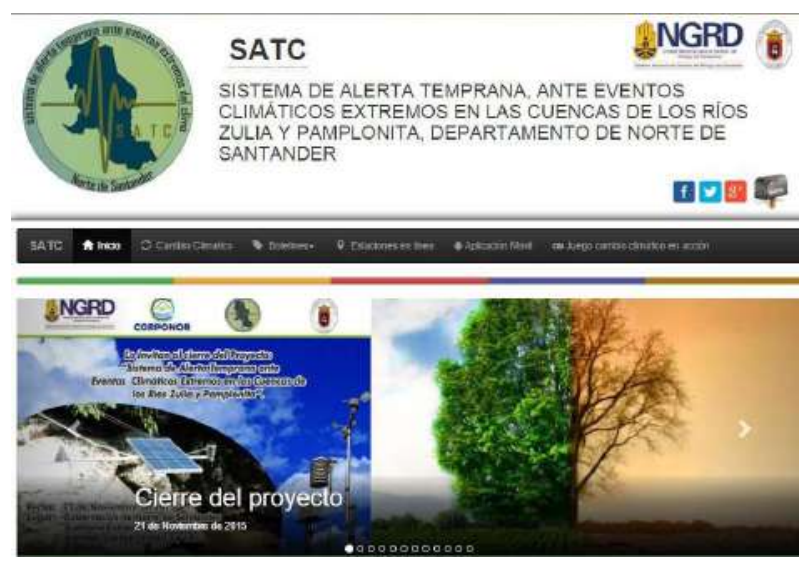

Figure 7 WebSIG Platform SAT project

Figure 8, shows the network of hydro-meteorological stations installed in the SAT project for the Pamplonita and Zulia river basins in the department of Norte de Santander, indicating the weather stations in green and the hydrological stations in blue.

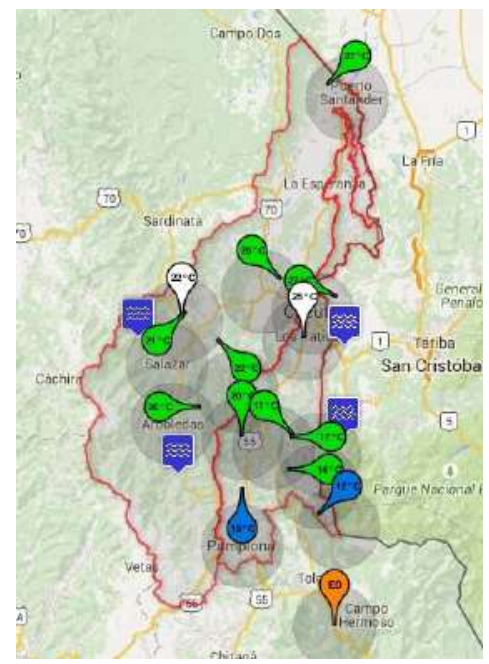

Figure 8 Hydro-meteorological stations online SAT project

\subsection{Community participation}

In this phase of development, parallel to the generation of information and the operation of the SAT, the regional participants of the SAT were trained in key issues for its operation, such as variability and climate change, adaptation, early warnings, reading and communication. handling of hydrometeorological instruments. risk management, meteorology, GIS, among others, through courses, demonstration plots, brochures, brochures, manuals, among others. Likewise, three workshops were held with SAT actors in Norte de Santander through the SAT diploma courses (Figure 9), on topics of Early Warning Systems against extreme weather events as a measure of adaptation to climate change and Climate change: signals, territorial distribution, impacts and adaptation measures in the Pamplonita river basin and climate variability and change with a focus on knowledge of early warning systems as a measure to reduce risk and disaster. Based on these inputs, developed within the framework of the SAT project, the AACC program and the Ordenando Nuestra Cuenca project, the design of the final awareness material that will complement the project was delivered to communities, SAT users and key stakeholders. in the region. 110 actors and participants were trained in topics that included climate variability, climate change, meteorological instruments, adaptation to climate change and the use of SATC as a tool to support decision-making around Risk Management. Likewise, it was necessary to promote the linking of the technical component with the current and ancestral knowledge of the communities through dialogue. Long-term regional courses and local replicas are a key strategy for spreading knowledge about variability, climate change and adaptation.

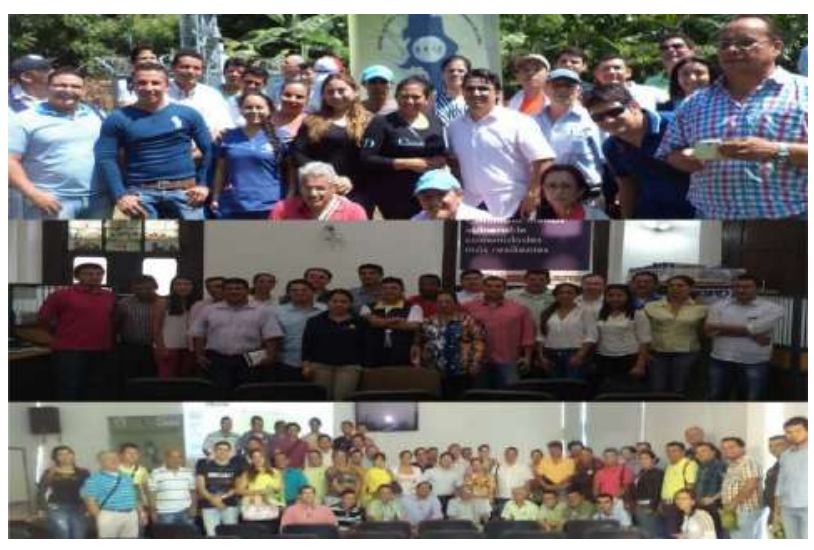

Figure 9 Training for SAT project actors

\section{Conclusions}

The application of a disaster risk reduction strategy through an early warning system for extreme weather events is important as a tool and instrument for planning risk management and higher risks, since corrective measures can be taken. In the same way, in view of the constant growth of disaster risk, including the increase in the degree of exposure of people and goods, combined with the lessons learned from previous disasters, the following stand out: the need to further strengthen disaster preparedness, acting before the events that integrate disaster risk reduction into preparedness and making sure there is sufficient capacity for effective response 
and recovery at all levels. It is necessary to include a sustainability strategy through the linkage, training and active participation of regional institutions such as the Government, municipal governments, universities, as well as social and non-governmental organizations of the basin so that they can resume the project once this period of execution is over. Likewise, the creation of a network of local observers for local climate monitoring. Linkage, training and participation of communities and their participation in the generation of early community alerts. In addition, the exchange of experiences, knowledge and methodologies with other national and international systems for the generation of early warnings. creation of a Network of Adaptation to the Climate of Norte de Santander RedACNS, with a line of work in Early Alerts for Norte de Santander. Similarly, to generate capacities in the region for climate monitoring and the generation of early warnings due to extreme weather phenomena and the use of simple installation equipment, low cost, easy maintenance, high compatibility and ease of sending data to the internet and GPRS data.

\section{References}

[1] Lineamientos de manejo para el casco urbano destruido del municipio de Gramalote. Norte de Santander, Alcadía de Gramalote, San José de Cúcuta, Colombia, 2011.

[2] "Convención marco de las naciones unidas sobre el cambio climático," UNFCCC, New York, USA, 1992.

[3] Cambio climático 2007: Informe de síntesis, in Contribución de los Grupos de trabajo I, II y III al Cuarto Informe de evaluación del Grupo Intergubernamental de Expertos sobre el Cambio Climático, IPCC, Geneva, Switzerland, 2007.

[4] J. D. Pabón and R. Chaparro, "Colombia en el ambiente global," in El Medio Ambiente en Colombia, P. Leyva, Ed. bogota colombia: slnstituto de Hidrología, Meteorología y Estudios Ambientale, 1998. pp. 18-37.

[5] J. Montealegre and J. Pabón, “La variabilidad climática interanual asociada al ciclo el niño-la niña-oscilación del sur y su efecto en el patrón pluviométrico de colombia," Meteorol. Colomb., vol. 2, pp. 7-21, 2000.

[6] M. Bedoya, C. Contreras, and F. Ruiz, "Alteraciones del régimen hidrológico y de la oferta hídrica por variabilidad y cambio climático," in Estudio Nacional del Agua, J. M. Santos and et al., Eds. Bogotá, colombia: Instituto de Hidrología, Meteorología y Estudios Ambientales, 2010, pp. 282-318.
[7] Metodologías para generar y utilizar información meteorológica a nivel subnacional y local frente al cambio climático, 4th ed., Programa AACC, Bonn, Alemania, 2011.

[8] J. D. Pabón and J. E. Montealegre, "Efectos naturales y socioeconómicos del fenómeno frío del pacífico (La Niña)," IDEAM, Bogotá, Colombia, Tech. Rep. IDEAM-METEO/ 007-98, 1998.

[9] (2012) Información en formato shape sobre impactos del fenómeno de la niña 2010-2011. CORPONOR. Accessed Nov. 13, 2018. [Online]. Available: https://corponor.gov.co/web/

[10] R. Basher, "Global early warning systems for natural hazards: Systematic and people-centered. philosophical transactions," Series A, Mathematical, physical and engineering sciences, vol. 364, no. 1845, pp. 2167-2182, Mar. 2006.

[11] S. Davies, S. M. Buchanan, and R. Lambert. (1991) Early warning in the sahel and horn of africa: The state of the art. a review of the literature. IDS Research Report. Brighton, U.K.

[12] UNISDR. (2009) Terminology on disaster risk reduction. United Nations. Geneva, Switzerland.

[13] UNEP \& GEAS, "A state-of-the-art analysis and future directions," Environmental Development, vol. 4, pp. 136-171, 2012.

[14] E. Calle and S. Báez, “Estado del arte de los sistemas de alerta temprana en colombia," Revista Académica Colombiana Ciencias de la Tierra, vol. 38, no. 148, pp. 321-32, 2014.

[15] F. Ghesquiere and O. Mahul. (2010) Financial protection of the state against natural disasters: A primer. World Bank Policy Research Working Papers. Washington, D.C., USA.

[16] L. E. Yamin, Modelación probabilista para la gestión del riesgo de desastre: el caso de Bogotá, Colombia. Bogotá, Colombia: Universidad De Los Andes, 2013.

[17] D. Alzate, E. Rojas, J. Mosquera, and J. Ramón, “Cambio climático y variabilidad climática para el periodo 1981-2010 en las cuencas de los ríos zulia y pamplonita, norte de santander, colombia," Luna Azul, vol. 40, 2015. [Online]. Available: http: //dx.doi.org/10.17151/luaz.2015.40.10.

[18] UNISDR, “Plan de acción regional para la implementación del marco de sendai para la reducción del riesgo de desastres 2015 - 2030 en las américas," in $5^{\text {th }}$ regional platform for disaster risk reduction in the americas, Montreal, Canada, 2017, pp. 1-5.

[19] (2015) Estructura del sistema nacional de gestión de riesgo de desastre. UNGRD. Accessed Nov. 13, 2018. [Online]. Available: https://bit.ly/2fAbrfC

[20] F. Boshell, “Las alertas agroclimáticas tempranas participativas: punto de encuentro entre conocimientos actuales y ancestrales y apoyo para la seguridad alimentaria," in Diálogo Local Caribe Colombia Seguridad Alimentaria y Adaptación al Cambio Climático. GIZ- Programa AAC y Red Nacional Cambio Climático y Seguridad Alimentaria de Colombia - RICCLISA, Popayán, Colombia, 2013.

[21] J. R. Palacios, J. A. Ramon, and K. C. Herrera, “Generation of prognostics of the state of time for the early alert system of the pamplonita river basin," Contemp. eng. sci., vol. 11, no. 49, 2018. [Online]. Available: https://doi.org/10.12988/ces.2018.85241 